\title{
PEMBERDAYAAN KOMITE SEKOLAH UNTUK PENINGKATAN MUTU PENDIDIKAN DALAM IMPLEMENTASI KURIKULUM 2013 DI SD NEGERI
}

\author{
Zulfadli Hamdi ${ }^{1}$, Sugeng Bayu Wahyono ${ }^{2}$ \\ zulfadli.hamdi15@gmail.com,sugeng_bw@uny.ac.id
}

\begin{abstract}
Abstrak
Tujuan penelitian ini adalah untuk mendeskripsikan dan mendalami: (a) dinamika peran dan fungsi Komite Sekolah dalam peningkatan mutu pendidikan di SDN 3 Pancor, (b) peran dan fungsi Komite Sekolah dalam peningkatan mutu pendidikan di SDN 3 Pancor, (c) faktor pendukung dan penghambat Komite Sekolah dalam peningkatan mutu pendidikan di SDN 3 Pancor, dan (d) bentuk pemberdayaan komite sekolah dalam peningkatan mutu pendidikan di SDN 3 Pancor. Pendekatan yang digunakan dalam penelitian ini adalah kualitatif. Subyek penelitian terdiri dari kepala sekolah, guru, dan komite sekolah, dan orang tua siswa di SDN 3 Pancor. Data penelitian dikumpulkan melalui wawancara, observasi, dan analisis dokumen. Data penelitian ini dianalisis menggunakan teknik analisis kualitatif secara interaktif diantaranya pengumpulan data, reduksi data, penyajian data, dan penarikan kesimpulan. Hasil penelitian menunjukkan bahwa dinamika komite sekolah yang terjadi bahwa pemberdayaan komite sekolah di SDN 3 Pancor belum maksimal. Komite sekolah telah menjalankan empat perannya namun tidak berjalan dengan efektif sehingga perlu ditingkatkan. Faktor pendukung peran komite sekolah adalah (a) adanya komitmen yang tinggi dari komite sekolah untuk membantu sekolah; (b) dukungan ide, tenaga, dan fasilitas yang memadai; (c) terjalinnya komunikasi dan koordinasi yang baik; (d) latar belakang pendidikan anggota komite sekolah; dan selama ini uapaya sekolah dalam memberdayakan komite sekolah hanya sebatas diskusi yang sifatnya insidental.
\end{abstract}

Kata kunci: pemberdayaan, komite sekolah, mutu pendidikan. 


\section{PENDAHULUAN}

Globalisasi yang ditandai dengan persaingan yang sangat ketat dalam semua aspek kehidupan, memberi warna/pengaruh terhadap tuntutan akan kualitas Sumber Daya Manusia (SDM), termasuk sumber daya pendidik sebagai unsur yang mempunyai posisi sentral dan srtategis dalam pembentukan SDM yang berkualitas. Pembangunan SDM yang berkualitas memerlukan proses yang cukup panjang dan keterlibatan semua pihak. Diantaranya adalah keterlibatan lembaga pendidikan. Lembaga-lembaga pendidikan pada saat ini tumbuh dan berkembang pada kondisi tuntutan demokrastisasi pendidikan, akuntabilitas, tuntutan kualitas, dan jaminan mutu dari dunia kerja. Berbagai persoalan yang muncul dalam penyelenggaraan pendidikan di Indonesia, salah satunya adalah rendahnya mutu pendidikan pada setiap jenjang dan satuan pendidikan, khususnya pendidikan dasar. Salah satu dari sekian banyak penyebab adalah karena kurangnya pemberdayaan masyarakat dalam rangka pengambilan keputusan, kebijakan, memberikan pertimbangan, dan arahan dalam bentuk program-program yang akan dilaksanakan oleh sekolah.

Pendidikan adalah tanggung jawab bersama antara orang tua, masyarakat dan pemerintah. Dapat dikatakan saat ini tanggung jawab masing-masing belum optimal, terutama peran serta masyarakat yang masih dirasakan belum banyak diberdayakan. Oleh karena itu, secara hakiki, pembangunan pendidikan merupaka bagian yang tidak dipisahkan dalam upaya pembangunan manusia. Upaya-upaya pembangunan dibidang pendidikan, pada dasarnya diarahkan untuk mewujudkan kesejahteraan manusia itu sendiri. Karena pendidikan merupakan hak setiap warga negara, di dalamnya terkandung makna bahwa pemberian layanan pendidikan kepada individu, masyarakat, dan warga negara adalah tanggung jawab bersama antara pemerintah, masyarakat dan keluarga.

Menurut (Ife, 2006, p.67) bahwa empowerment is a process of helping disadvantaged groups and individual to compete more effectively with other interests, by helping them to learn and use in lobbying, using the media, engaging in political action, understanding how to 'work the system,' and so on.

Hal yang berbeda diungkapkan Sulistiyani (2004, p. 77) menjelaskan bahwa pemberdayaan dapat dimaknai sebagai suatu proses menuju berdaya, atau proses untuk memperoleh kekuatan, dan atau proses pemberian kekuatan dari pihak yang 
memiliki daya kepada yang kurang atau belum berdaya. Artinya konsep pemberdayaan (empowerment) sebagai upaya memberikan otonomi, wewenang, dan kepercayaan kepada setiap individu dalam suatu organisasi, serta mendorong mereka untuk kreatif agar dapat menyelesaikan tugasnya sebaik mungkin. Oleh karena itu pemberdayaan sangat jauh dari konotasi ketergantungan. Jadi bisa juga dikatakan bahwa pemberdayaan merupakan upaya menggalang potensi yang ada dimasyarakat secara praktis dan produktif untuk mencapai tujuan dengan pemberian daya dan kekeuatan untuk melaksanakan atau target yang akan dicapai.

Dalam proses pemberdayaan, Guru merupakan subjek dan murid merupakan objek yang harus "diisi" dengan informasi dalam proses pembelajaran seperti ini maka dialog merupakan unsur penting karena guru dan murid belajar bersama atau saling belajar, guru dan murid bersama-sama mengembangkan kemampuannya untuk mengerti secara kritis dirinya sendiri dan dunianya, dunia merupakan realitas dalam proses, Inti dialog (Sastraprateja, 2013, pp.26-27).

Hubungan antara guru dan siswa dilakukan secara demokratis dimana terjadinya hubungan yang simbiotik. pendidikan demokrasi dibangun dan dikembangkan sesuai dengan aspirsai dan kebutuhan rakyatnya, agar setiap individu bisa bebas berkembang menurut kodratnya. Pada perinsipnya, pendidikan demokrasi adalah suatu proses, dimana siswa berpartisipasi dalam pengambilan keputusan yang akan mempengaruhi kehidupan sekolah (Zamroni, 2013, p. 20). Keterlibatan siswa yang diartikan sebgai proses partisipasi ini merupakan hal yang mendukung dalam pengambilan keputusan yang akan berdampak atau berpengaruh bagi kehidupan sekolah. Selanjutnya pemberdayaan yang baik akan mempengaruhi kualitas dan mutu pendidikan. (Sallis, 2006, p.51) menjelaskan tentang konsep mutu merupakan sesuatu yang absolut dan relatif. Mutu yang absolut merupakan mutu yang idealismenya tinggi dan harus terpenuhi, bersetandar tinggi, dengan sifat produk bergengsi tinggi. Sekolah bukan sebagai lembaga yang menghasilkan produk berupa barang tetapi dikatagorikan sebagai lembaga yang memberikan layanan jasa.

Mutu di bidang pendidikan meliputi mutu input, proses, output, dan outcome. Input pendidikan dinyatakan bermutu jika siap berproses. Proses pendidikan bermutu apabila mampu menciptakan suasana yang PAKEMB (Pembelajaran yang Aktif, Kreatif, Efektif, Menyenangkan, dan Bermakna). Output dinyatakan bermutu jika 
hasil belajar akademik dan non akademik siswa tinggi. Outcome dinyatakan bermutu apabila lulusan cepat terserap di dunia kerja, gaji wajar, semua pihak mengakui kehebatan lulusan dan merasa puas.

Pengendalian mutu dapat dilakukan oleh siapa saja yang terlibat dalam pendidikan. Dalam MBS sekolah dapat merencanakan, menetapkan, dan melaksanakan sendiri kebijakan, program, dan kegiatan sekolah, sepanjang untuk memajukan institusi sekolah dan meningkatkan mutu pendidikannya (Bafadal, 2006, p.86). Oleh karena itu, Sekolah harus dapat menjalin dan bekerja sama dengan semua stakeholder pendidikan (Suparlan, 2008, p.30).

Pencapaian mutu pendidikan yang berkualitas tentu merupakan harapan besar bagi setiap institusi pendidikan. Hendaknya pendidikan mampu melahirkan lapisan masyarakat terdidik dan menjadi kekuatan yang merekatkan unit-unit sosial di dalam masyarakat. Kurikulum 2013 yang digunakan saat ini merupakan uapaya pembaharuan dalam sistem pendidikan Indonesia. Seiring dengan kepastian pemerintah terkait terkait terkait dengan pengembangan Kurikulum KTSP menuju Kurikulum 2013 memunculkan sebuah tantngan baru bagi setiap institusi pendidikan. Maka dari itu sosialisasi dan pelatihan Kurikulum 2013 terhadap guruguru sebagai pelaksana di lapangan menjadi sebuah hal yang penting dan wajib hukumnya. Mengingat, guru sebagai motor utama penentu keberhasilan penerapan Kurikulum 2013 ini di lapangan. Kesiapan dan pemahaman guru terhadap ruh Kurikulum 2013 harus dimiliki oleh semua guru. Pemahaman guru terhadap ruh Kurikulum 2013 inilah yang akan menjadikan guru bisa melakukan tindakan yang sesuai dengan maksud dan tujuan yang ada dalam Kurikulum 2013. Dengan demikian kesiapan dan pemahaman guru terhadap Kurikulum 2013 ini menjadi hal yang sangat menentukan dalam keberhasilan dan pencapaian tujuan dari Kurikulum 2013 (Arifin, 2014, p.174).

Upaya sekolah mengontrol mutu pendidikannya memungkinkan sekolah tersebut menjadi sekolah bermutu. Arcaro (2007, p.2) mengatakan manajemen mutu merupakan sarana yang memungkinkan para profesional pendidikan dapat beradaptasi dengan "kekuatan perubahan" yang menghantam sistem pendidikan kita. Hal yang berbeda diungkapkan oleh (Zamroni, 2001, p.147) dalam rangka meningkatkan mutu sekolah, selain melakukan pendekatan konvensional (inpud 
oriented) sebagaimana selama ini perlu diiringi pula dengan pendekatan inkonvensional, yaitu membangun budaya sekolah. Artinya dalam peningkatan mutu pendidikan pentingnya membangun budaya sekolah, dengan membengun buadaya sekolah yang baik maka akan tercipta sekolah yang berkualitas dan akan berdampak pada perubahan sistem pendidikan pada tiap institusi yang sangat berkualitas.

Hoy \& Ferguson (1985, p.117) mengemukakan bahwa ada dua model teoritik yang dijadikan sebagai pendekatan yang sangat berguna dalam menetapkan sekolah yang baik, yaitu model tujuan dan model sistem. Model tujuan pada dasarnya merupakan sebuah pendekatan yang berlandaskan pada sebuah perencanaan yang dimana apa yang telah menjadi perencanaan dapat terlaksana berdasarkan sesuai denga apa yang menjadi tujuan pencapaian. Sedangkan pada model sistem

UNICEF (2000, pp.3) menyebutkan bahwa indikator sekolah bermutu yaitu, (1) Learners who are healthy, well-nourished and ready to participate and learn, and supported in learning by their families and communities; (2) Environments that are healthy, safe, protective and gender-sensitive, and provide adequate resources and facilities; (3) Content that is reflected in relevant curricula and materials for the acquisition of basic skills, especially in the areas of literacy, numeracy and skills for life, and knowledge in such areas as gender, health, nutrition; (4) Processes through which trained teachers use child-centred teaching approaches in well-managed classrooms and schools and skilful assessment to facilitate learning and reduce disparities; (5) Outcomes that encompass knowledge, skills and attitudes, and are linked to national goals for education and positive participation in society.

Berdasarkan pada pendapat tersebut dapat dijelaskan bahwa indikator sekolah bermutu itu adalah meliputi pembelajar yang sehat, terawat dengan baik dan siap untuk berpastisipasi dan belajar, serta terdukung daam pembelajaran oleh keluarga dan komunitas mereka; lingkungan yang sehat, aman, terlindungi, dan tersedianya sumber daya dan fasilitas yang memadai; konten yang direfleksikan dalam kurikulum yang relevan dan materi demi kematangan keterampilan dasar, khususnya pada literasi, numerasi dan keterampilan hidup, dan pengetahuan dalam seperti ranah jenis kelamin, kesehatan, nutrisi, dan kedamaian; berproses yang mana guru yang terlatih menggunakan pendekatan pembelajaran child-center dalam mengelola kelas dan sekolah yang baik serta penilaian keahlian untuk memfasilitasi pembelajaran dan mengurangi perpecahan; dan hasil yang meliputi pengetahuan, keterampilan dan sikap, serta yang terhubung pada tujuan nasional untuk pendidikan dan partisipasi positif dalam masyarakat. 
Komite sekolah sebagai badan mandiri strategis yang mewadahi peran serta masyarakat dalam rangka meningkatkan mutu, pemerataan, dan efisiensi pengelolaan pendidikan di satuan pendidikan. Komite Sekolah yang dibentuk untuk menunjang penyelenggaraan sistem pendidikan di sekolah berperan untuk meningkatkan kualitas pelayanan pendidikan, untuk mewadahi dan meningkatkan partisipasi para stakeholder sekolah untuk turut merumuskan, menetapkan, melaksanakan, dan memonitor pelaksanaan kebijakan sekolah dan pertanggungjawaban yang terfokus pada kualitas pelayanan terhadap peserta didik secara proporsional dan terbuka.

Esensi dari partisipasi Komite Sekolah adalah peningktkan kualitas pengambilan keputusan dan perencanaan sekolah yang dapat mengubah pola pikir, keterampilan, dan distribusi kewenangan atas individual dan masyarakat yang dapat memperluas kapasitas manusia meningkat taraf hidup dalam sistem manajemen pemberdayaan sekolah. Pemberdayaan komite sekolah adalah membuat orang-orang yang duduk sebagai pengurus dan anggota komite menjalankan perannya untuk membantu penyelengaaraan pendidikan. Misalnya memobilisasi dana masyarakat ataupun dalam bentuk sumbangan lainnya seperti memberikan pertimbangan dan pemikiran

Menurut (Hasbulloh, 2006, p.95) pembedayan komite sekolah secara optimal, termasuk dalam mengawasi penggunaan keuangan, transparansi alokasi dana pendidikan lebih dapat dipertanggung jawabkan. Pengembangan pendidikan secara lebih inovatif juga akan semakin memungkinkan, disebabkan lahirnya ide-ide cemerlang, dan kreatif semua pihak terkait (stakeholder) pendidikan. Komite Sekolah harus dibentuk berdasarkan pada prakarsa masyarakat yang peduli pendidikan, bukan didasarkan pada arahan atau instruksi dari lembaga pemerintahan. Pembentukan komite sekolah harus dilakukan secara transparan, akuntabel, dan demokratis. Transparan berarti pembentukan komite sekolah dilakukan secara terbuka dan diketahui oleh masyarakat khususnya masyarakat lingkungan sekolah mulai dari tahap pembentukan panitia persiapan, sosialisasi oleh panitia persiapan, penentuan kriteria calon anggota, pengumuman calon anggota, proses pemilihan, sampai penyampaian hasil pemilihan kepada masyarakat.

Hasbulloh (2006, pp.92-93) menjelaskan bahwa peran dan fungsi komite sekolah adalah sebagai berikut: 1) Pemberi pertimbangan (advisory agency). 2) Pendukung 
(supporting agency). 3) Pengontrol (controlling agency). 4) Mediator (mediator agency). Sedangkan Mupindu menjelaskan tugas dari komite sekolah adalah

"In all public schools, School Development Committees/School Development Associations have been established and charged with the responsibility of adopting a constitution and developing the mission statement of the school; adopting a code of conduct for the learners, determining school times; developing a budget and determining school fees; administering school property and buildings, and making recommendations for the appointment of educators and non-teaching staff".

Pada intinya adalah komite pengembangan sekolah didirikan dan dibebankan dengan tanggungjawab untuk mengadopsi konstitusi dan mengembangakan misi sekolah.

Keputusan Mendiknas Nomor 044/U/2002 tentang dewan pendidikan dan komite sekolah dijelaskan bahwa keanggotaan komite sekolah terdiri dari: 1) Unsur masyarakat dapat berasal dari orang tua/wali murid, tokoh masyarakat, tokoh pendidikan, dunia usaha/industri, organisasi profesi tenaga kependidikan, wakil alumni, wakil peserta didik. 2) Unsur dewan guru, yayasan/lembaga penyelengaara pendidikan, Badan Perwakilan Desa (BPD) maksimal tiga orang.

\section{METODE PENELITIAN}

Peneletian ini menggunakan metode deskriptif dengan menggunakan pendekatan kualitatif (naturalistik). Adapun beberapa alasan digunakan pendekatan ini adalah: 1) penelitian tentang pemberdayaan komite sekolah dalam peningkatan mutu pendidikan berhubungan langsung dengan masalah perilaku manusia sosial masyarakat dan dalam setting alamiah, 2) masalah penelitian yang dikaji sangat deskriptif, 3) peneliti sebagai key instrumen, 4) dalam menentukan responden sebagai informan digunakan purposive.

\section{Waktu dan Tempat Penelitian}

Penelitian ini dilaksanakan di SD Negeri 3 Pancor Kecamatan Selong Lombok Timur. Penelitian ini dilaksanakan selama dua bulan, yaitu mulai bulan Februari sampai Maret 2015.

\section{Subjek atau Responden}

Subjek yang dipilih pada penelitian ini adalah kepala sekolah, guru, komite sekolah, anggota komite sekolah, dan orang tua siswa di SD Negeri 3 Pancor. 


\section{Teknik Pengumpulan Data}

Pada penelitian ini teknik pengumpulan data yang digunaka yaitu; pengamatan (observasi), wawancara mendalam (deep interview), dan dokumentasi.

\section{Teknik Analisis Data}

Analisis data yang digunakan pada penelitian ini adalah analisis data kualitatif, analisis data pada dasarnya sudah dilakukan sejak awal kegiatan penelitian sampai akhir penelitian. Analisis data penelitian ini menggunakan analisis model interaktif dari (Miles dan Hubermen, 1994, p.12). Analisis data model interaktif adalah upaya berlanjut, berulang dan terus menerus antara melakukan pengumpulan data (data colection), reduksi (data rudction), penyajian data (data display) mengambil kesimpulan (conclusions drawing/verification) sebagai berikut:

\section{HASIL PENELITIAN DAN PEMBAHASAN}

\section{Hasil}

Kondisi geografis SD Negeri 3 Pancor dekat dengan lingkungan masyarakat, hal ini mengindikasikan hubungan sekolah dengan masyarakat tidak ada jarak dan ini memungkinkan memiliki pengaruh besar terhadap perkembangan sekolah di SD Negeri 3 Pancor. Kondisi pendidikan masyarakat rata-rata orang-orang yang sudah mengenyam dunia pendidikan dan sebagian besar dari masyarakat setempat sudah berpendidikan tinggi. Keberadaan komite sekolah di SD Negeri 3 Pancor merupakan harapan besar bagi masyarakat untuk bisa mewakili masyarakat dalam menyampaikan aspirasi, keluhan, ide, saran dan hal-hal lain dalam rangka memajukan sekolah. Sebagaimana diungkap oleh komite sekolah yang menyatakan bahwa

Awal dari keberadaan komite sekolah SD Negeri 3 Pancor dilandasi karena memang pada awal berdirinya SD Negeri 3 Pancor ini berlandaskan pada adanya harapan dari masyarakat sekitar sekolah yang menginginkan adanya sebuah lembaga pendidikan yang bisa mengajar dan mendidik anak-anak mereka yang dapat menjadi wakil dari masyarakat untuk menyampaikan aspirasi, keluhana, ide, saran dan hal lainnya dalam rangaka memajukan sekolah. Pengurus komite sekolah SDN 3 Pancor terdiri dari unsur tokoh masyarakat, wali/orang tua siswa, pengusaha, tokoh pendidikan, dan guru di sekolah tersebut. Pembentukan komite sekolah ini diikuti oleh beberapa unsur seperti yang disampaikan oleh Ketua komite sekolah SD Negeri 
3 Pancor bahwa dalam pembentukan pengurus komite sekolah, pihak sekolah melibatkan beberapa unsur yaitu orang tua siswa, tokoh masyarakat, pemerhati pendidikan, dan stakeholder sekolah. Hal ini dilakukan agar setiap elemen dapat berperan serta dalam memajukan sekolah dan menjunjung tinggi transparansi dan akuntabilitas sekolah terhadap program kerja yang dilakukan oleh sekolah .

Evaluasi penyelenggaraan pendidikan selalu dilakukan. Evaluasi merupakan langkah yang dilkukan oleh komite sekolah dengan pihak sekolah guna mengutahui sejauh mana program yang sudah dirancang sudah terlaksana atau tidak dan apakah terdapat kendala yang ditemukan dalam proses pelaksanaannya. Dalam hasil wawancara dengan salah satu informan menyatakan bahwa setiap pertengahan dan akhir tahun sekolah mengundang komite sekolah untuk membahas program kerja yang telah berjalan. Membahas kendala yang dihadapi dalam pelaksanaan program kerja serta membahas kendala yang dihadapai dalam pelaksanaan program kerja serta membahas solusi, agar tidak terjadi lagi ditahun berikutnya.

Dalam menjalankan perannya, komite sekolah menyetujui dan mengesahkan program yang dirancang oleh pihak sekolah, namun komite sekolah belum sepenuhnya memberikan pertimbangan dari rancangan program, dan hanya sebatas memberikan persetujuan dan mengesahkan draft program yang diajukan pihak sekolah. Komite sekolah dalam hal ini belum begitu memahami perannya dalam perencanaan program pendidikan yang sudah diatur dalam Undang-Undang Sitem Pendiidkan Nasional Nomor. 20 tahun 2003 mengenai keterlibatan komite sekolah secara langsung mulai dari perencanaan, pengawasan dan sampai pada pengawasan pelaksanaan program pendidikan.

Secara kualitas tenaga pendidik SD Negeri 3 Pancor cukup baik. Pada proses pembelajaran, sarana dan prasarana sangat mendukung untuk kemajuan siswa. Sarana dan prasarana yang dimilki SD Negeri 3 Pancor dalam menunjang proses pembelajaran yang bermutu SD Negeri 3 Pancor berupa gedung sekolah yang sudah dilengkapi dengan kompiuter, LCD, dan alat peraga serta media pembelajaran, perpustakaan, laboraturium IPA, laboraturium bahasa, ruang kompiuter, ruang UKS serta musolla yang dijadikan sebagai tempat praktik untuk pelajaran agama dan dijadikan tempat pelaksanaan imtaq bagi siswa 
Peran serta komite sekolah SD Negeri 3 Pancor dalam memberikan dukungan pendiidkan sangatlah minim, terutama dalam hal pemberian dukungan anggaran yang berasal dari masyarakat. Minimnya peran serta komite sekolah dalam pengadaan anggaran pendidikan di SD Negeri 3 Pancor sangatlah berpengaruh terhadap program kerja yang dirancang oleh sekolah karena setiap program kerja yang akan dilaksanakan tentunya tidak terlepas dari anggaran. Minimnya pengawasan yang dilakukan oleh komite sekolah berdampak pada kurangnya informasi yang objektif yang diperoleh oleh komite sekolah sehingga berdampak pada penilaian komite sekolah terhdap kinerja pendidik dan output yang dimilki oleh sekolah.

Adapun faktor pendukung dari kinerja komite sekolah dalam peningkatan mutu pendidikan di SD Negeri 3 pancor adalah: 1) Adanya komitmen yang tinggi dari komite sekolah untuk membentu sekolah. 2) Latar belakang pendidikan sebagian anggota komite sekolah dan 3) Kepala sekolah yang selalu proaktif. Dukungan ide, tenaga, dan terjalinnya komunikasi yang baik dari kepala sekolah. Faktor penghambat datang dari komite sekolah itu sendiri seperti kurangnya pemahaman anggota komite sekolah mengenai peran dan fungsi yang harus dijalankan, kurangnya kesadaran masyarakat akan pentingnya kualitas pendidikan, kurangnya dukungan yang diberikan oleh masyarakat terutama dalam hal anggaran dari komite sekolah, serta kesibukan yang dialami oleh komite sekolah itu sendiri

Upaya pemberdayaan komite sekolah untuk memperoleh dukungan dana, tenaga, ide, maupun fasilitas dari komite sekolah di SDN 3 Pancor yaitu dengan cara komite sekolah diundang dalam rapat-rapat sekolah yang bersifat umum dan terbuka, selain itu komite sekolah diundang dalam kegiatan-kegiatan akademik maupun non akademik terkait dengan penggunaan dana dalam rapat pembahasan RAPBS dan rapat pembahasan program kerja tahunan.

Pemberdayaan komite sekolah di SD Negeri 3 Pancor dilakukan dengan cara konsultasi pihak sekolah dengan komite sekolah dalam implementasi program sekolah, misalnya terjadi pada kegiatan penyusunan RAPBS, penyelenggaran program Rintisan Sekolah Bertaraf Internasional (RSBI), dan sebagainya. Semuanya dilakukan dengan membicarakan segala masalah, keluhan, dan kemajuan yang terkait 
dengan pelaksanaan program sekolah. Dengan harapan banyak masukan, ide maupun pendapat terhadap pelaksanaan program sekolah.

Keputusan/kebijkan yang diambil sekolah dilakukan atas dasar musyawarah mufakat dengan pihak komite sekolah. Keputusan/kebijakan tersebut adalah bersifat umum, strategis, dan keputusan/kebijakan itu memang diatur harus atas persetujuan komite sekolah misalnya penyusunan RAPBS. Namun demikian, ada beberapa keputusan/kebijakan sekolah yang tidak selalu membutuhkan musyawarah mufakat dengan komite sekolah. Keputusan/kebijakan sekolah yang bersifat harian, oprasional, atau juga keputusan/kebijakan yang menyangkut hal-hal yang menjadi otonomi pendidik misalnya penentuan nilai siswa atau kelulusan siswa.

Sinergisitas yang dibangaun menjadi tanggung jawab bersama antar sekolah dan masyarakat sebagai mitra kerja dalam membangun pendidikan. Sinergisitas yang dibangun oleh kedua unsur tersebut akan mencapai hal yang positif untuk kemajuan sekolah. Misalnya masyarakat dapat menyalurkan berbagai ide dan partisipasinya dalam memajukan sekolah untuk mencapai tujuan tersebut maka pemahaman dari unsur-unsur pendidikan tentang hak dan kewajiban yang harus dilaksanakan.

Pemahaman bebrapa anggota komite sekolah mengenai peran dan fungsi komite sekolah di SD Negeri 3 Pancor sudah dapat dikatakan sudah sesuai dengan SK Mendiknas RI No. 044/U/2002 tentang dewan pendidikan dan komite sekolah. Komite sekolah di SD Negeri 3 Pancor berperan sebagai pemberi pertimbangan, pendukung, pengontrol, dan penghubung. Dalam dimensi oprasional, komite sekolah di SD Negeri 3 Pancor berperan sebagai pemberi pertimbangan dalam penentuan dan pelaksanaan kebijakan, serta berperan sebagai pendukung sekolah, baik yang berwujud finansial, pemikiran, maupun tenaga dalam peningkatan mutu pendidikan. Namun dukungan yang berwujud finansial masih belum terealisasi dari peran komite sebagai pendukung. Selain itu dalam rangka transparansi dan akuntabilitas penyelenggaraan dan keluaran pendidikan, komite sekolah berperan sebagai pengontrol dan mediator antara pemerintah dan masyarakat. Peran dan tugas komite sekolah inilah yang masih dipandang belum maksimal dilaksanakan di SD Negeri 3 Pancor.

Sosialisasi yang dilakukan mengenai peran dan fungsi komite sekolah di SD Negeri 3 Pancor yang masih belum maksimal dilakukan oleh komite sekolah. 
Sosialisasi yang dilakukan oleh komite sekolah kepada orang tau siswa dan masyarakat hanyalah sosialiasi semata tanpa ada tindak lanjut dari komite sekolah terutama mengenai progran kerja sekolah. Pembuatan program kerja sekolah disusun atau dirancang dalam rapat, dimana dalam rapat tersebut dihadiri oleh kepala sekolah, komite sekolah, orang tua serta stakeholder lainnya. Selain melaui forum rapat sekolah komite sekolah juga melakukan sosilaisasi melalui surat yang diberikan kepada orang tua siswa

Dalam penanganan sarana prasarana, Komite sekolah belum berperan aktif dalam pengadaan sarana yang bersumber dari swadaya masyarakat. Kerjasama komite sekolah mengenai penambahan fasilitas sekolah berupa banguan fisik sekolah dan keuangan serta masukan inisiatif belum tampak. Bentuk kerjasama antara komite dan sekolah yang diharapkan dapat meningkatkan mutu belajar dalam bentuk dukungan sarana dan prasarana serta memberikan inisitiatif misalnya dalam bentuk pengawasan belajar belum dilakukan oleh komite.

\section{Pembahasan}

Pendidikan memliki peranan penting dalam peningkatan kualitas sumber daya manusia. Pendidikan memenuhi secara penuh pertumbuhan ekonomi suatu bangsa. Oleh karena itu, masalah mutu pendidikan menjadi sangat strategis untuk dikaji. Secara umum mutu merupakan gambaran dan karakteristik menyeluruh dari barang atau jasa yang menunjukkan kemampuannya dalam memuaskan kebutuhan yang diharapkan. Dalam konteks pendidikan, mutu mencakup input, proses, dan output pendidikan (Depdiknas, 2002, p.21). Dari uraian tersebut dapat dipahami bahwa dalam usaha mencapai mutu pendidikan diperlukan kerjasama berbagai pihak, baik internal maupun ekstemal, baik warga sekolah, orang tua murid, masyarakat, kalangan dunia kerja. Hal ini senada dengan pendapat (Arcaro, 2005, p.56) bahwa mutu merupakan usaha menciptakan, suatu lingkungan di mana pendidik, orang tua, pejabat pemerintahan, wakil masyarakat, dan para pimpinan dunia kerja bekerja sama untuk menyediakan para siswa dengan sumber daya yang mereka butuhkan untuk memenuhi taantangan akademik dunia kerja, masyarakat sekarang dan yang akan datang.

Input SD Negeri 3 Pancor dapat dikatakan cukup bermutu, hal ini dilihat dari animo masyarakat yang berkeinginan memasukkan anak-anaknya untuk bisa sekolah 
di SDN 3 Pancor. SD Negeri 3 Pacor juga mempunyai tenaga pendidik yang rata-rata telah menempuh jenjang pendidikan SI bahkan ada juga yang menempuh jenjang S2, staf TU, konselor dan administrator yang mempunyai keahlian dibidangnya dan juga didukung oleh sarana dan prasarana yang lengkap khususnya untuk peningkatan mutu pendidikan, diantaranya adanya ruang kelas, mushalla yang cukup luas, tempat wudhu, karpet, peralatan shalat (misalnya: mukenah dan sarung), ruang audio seperti TV, VCD yang mendukung proses pembelajaran, buku-buku agama, LKS, perpustakaan, laboraturium IPA, bahasa, ruang komputer dan lingkungan sekolah yag asli dan nyaman. Dengan adanya fasilitas-fasilitas tersebut dapat mempermudah guru dan siswa untuk melaksanakan proses pembelajaran. Dengan dukungan sumber belajar dan kualitas tenaga pendidika yang dimiliki maka akan menjamin kualitas mutu yang dihasilkan. Begitu halnya dengan budaya sekolah yang ada di SD Negeri 3 Pancor. Budaya sekolah yang selalu diterapkan oleh sekolah adalah pembecaan surat yasin dan ayat-ayat pendek yang dilakukan di Musolla sebelum memulai proses pembelajaran dan dirangkaiakan dengan solat duha dan setipa hari jum'at sekolah mengadayakan pekan amal pada siswa. Hal ini dilakukan dengan tujuan proses pembiasaan hal baik terutama bersedekah harus ditanamakan kepada anak. Budaya sekolah yang baik mencerminkan seolah yang memiliki kualitas yang baik pula. Keberadaan budaya sekolah merupakan faktor penting pada sekolah-sekolah unggulan setingkat SSN dan RSBI karena aspek ini adalah harian proses pendidikan di sekolah (Muhtarom, 2013, p.197). Deal \& Petterson (2002, p.7) mengatakan bahwa pada level apapun, semua organisasi, khususnya sekolah berusaha meningkatkan prestasinya dengan mengembangkan sebuah sistem kebersamaan dari norma, kepercayaan, nilai dan tradisinya. Kemudian sekolah mulai menanamkan tradisi tersebut pada cita-cita, tujuan, dan semangat. Dijelaskan pula bahwa tanpa kekuatan, budaya yang positif, sekolah akan kesulitan dan tutup. Budaya sekolah memiliki peran penting dalam penanaman teladan dan peningkatan prestasi sekolah. Pendapat di atas kemudian dikuatkan pula oleh Hoy \& Miskel (2005, p.13) menyebutkan bahwa budaya sekolah yang baik akan meningkatkan prestasi dan motivasi siswa.

Output pendidikan yang dihasikan oleh SD Negeri 3 Pancor sudah cukup unggul dibandingkan dengan sekolah-sekolah yang lainyang ada kabupaten lombok timur. 
Dengan output pendidikan yang dimiliki nya maka SD Negeri 3 Pancor dijadikan sebagai sekolah pilot projec dalam implementasi kurikulum 2013 pada tingkat sekolah dasar di kabupaten Lombok Timur. Hal ini sesuai dengan yang ugkapkan (Danim, 2006, pp.53-54) menyatakan bahwa hasil (output) pendidikan dipandang bermutu jika mampu melahirkan keunggulan akademik dan ekstrakurikuler pada peserta didik yang dinyatakan lulus untuk jenjang pendidikan atau menyelesaikan program pembelajaran tertentu.

Terbentuknya komite sekolah di SD Negeri 3 Pancor merupakan harapan besar bagi masyarakat sekitar karena komite sekolah merupkan badan perwakilan masyarakat untuk menyampaikan aspirasi dan masukan kepada sekolah. namun apa yang terjadi berbeda dari apa yang diharapkan oleh masyarakat pada saat awal pembentukan komite sekolah. Dalam paradigma transisional, hubungan keluarga dan sekolah sudah mulai terjalin, tetapi belum terjalin hubungan yang konsisten dengan sekolah sebagai pengelola pendidikan formal. Dalam paradigma baru hubungan keluarga, sekolah, dan masyarakat terjalin secara sinergis untuk meningkatkan mutu layanan pendidikan, termasuk untuk meningkatkan mutu hasil belajar siswa di sekolah. pendidikan seharusnya membangun sinergisitas dalam peningkatan mutu pendidikan ang berkualitas tepai apa yang terjadi masih sangat jauh dari apa yang diharapkan. Kurangnya pemberdayaan masyarakat yang diberikan oleh sekolah dan kurangnya implementasi dari peran yang dijalankan oleh komite sekolah menyebebakan peran dan fungsi yang dijalankan masih tidak epektif.

Kemudian secara administrasi, komite sekolah masih kurang mampu memanajmen administrasi. Hal ini dibuktikan dengan tidak dilakukannya penyimpanan arsip/dokumen yang seharusnya dijadikan sebagai acauan atau landasan yang digunakan oleh komite sekolah dalam pelaksanaan peran dan fungsi yang dijalankan. Misalnya dalam peneimpanan AD/ART komite sekolah. (Purwanto, 2005, p.4) menyatakan bahwa administrasi pendidikan merupakan segenap proses pengarahan dan pengintegrasian segala sesuatu, baik personal, spiritual maupun material, yang bersangkut paut dengan pencapain tujuan pendidikan. Proses administrasi pendidikan segenap usaha orang-orang yang terlibat di dalam proses pencapain tujuan pendidikan itu diintegrasikan, diorganisasi, dan dikoordinasikan 
secara efektif, dan semua materi yang diperlukan dan yang telah ada dimanfaatkan secara efisien.

Komite sekolah dalam menjalankan peran dan fungsi komite sekolah, komite sekolah menyetujui dan mengesahkan program yang dirancang oleh pihak sekolah, namun komite sekolah belum sepenuhnya memberikan pertimbangan dari rancangan program, dan hanya sebatas memberikan persetujuan dan mengesahkan draft program yang diajukan pihak sekolah. Komite sekolah dalam hal ini belum begitu memahami perannya dalam perencanaan program pendidikan yang sudah diatur dalam Undang-Undang Sitem Pendiidkan Nasional Nomor. 20 tahun 2003 mengenai keterlibatan komite sekolah secara langsung mulai dari perencanaan, pengawasan dan sampai pada pengawasan pelaksanaan program pendidikan. (Uno, 2008, p.17) menyebutkan beberapa kegiatan yang memerlukan partisipasi masyarakat (komite sekolah) dalam upaya meningkatkan mutu pendidikan antara lain: (1) penyusunan rencana kerja sekolah, (2) penyusunan Rencana Anggaran Pendapatan Dan Belanja Sekolah (RAPBS), (3) pelaksanaan program pendidikan, dan (4) transparansi dan akuntabilitas pendidikan.

Adapun peran serta komite sekolah SD Negeri 3 Pancor dalam memberikan dukungan pendiidkan sangatlah minim, terutama dalam hal pemberian dukungan anggaran yang berasal dari masyarakat. Minimnya peran serta komite sekolah dalam pengadaan anggaran pendidikan di SD Negeri 3 Pancor sangatlah berpengaruh terhadap program kerja yang dirancang oleh sekolah karena setiap program kerja yang akan dilaksanakan tentunya tidak terlepas dari anggaran. Minimnya pengawasan yang dilakukan oleh komite sekolah berdampak pada kurangnya informasi yang objektif yang diperoleh oleh komite sekolah sehingga berdampak pada penilaian komite sekolah terhdap kinerja pendidik dan output yang dimilki oleh sekolah.

Komite SD Negeri 3 Pancor memang sudah mengupayakan perannya dalam peningkatan mutu sekolah, namun hanya bebrapa pengurus yang memiliki komitmen dalam melaksanakan perannya secara tugas dan fungsinya. Alasan klasik komite sekolah tidak mendapatkan bayaran bagi sebagian anggota merasa beban kerja dan tanggung jawab belum sebanding. Kecenderungan pengurus komite SD 
Negeri 3 Pancor belum memahami tugas dan fungsinya secara benar, sehingga peran yang diberikan untuk peningkatan mutu sekolah tidak maksimal.

Sementara itu Bank Dunia mendefinisikan pemberdayaan sebagai "the process of increasing the capacity of individuals or groups to make choices and to transform those choise into desired actions and outcomes". Artinya pemberdayaan dapat dimaknai sebagai proses peningkatan kapasitas individual atau kelompok untuk membuat pilihan dan untuk melaksanakan pilihan tersebut kedalam kegiatankegiatan dan hasil yang diharapkan. Dalam konteks kelembagaan komite sekolah, peningkatan kapasitas yang dimaksud adalah para anggota komite sekolah agar dapat melaksanakan peran secara optimal untuk meningkatkan mutu sekolah. Secara yuridis formal, SD Negeri 3 Pancor telah memiliki perangkat komite sekolah sebagai wakil masyarakat dalam membantu program sekolah. Namun kehadiran komite sekolah telah belum menunjukan peran sebagai mitra.

Adapun faktor pendukung dari kinerja komite sekolah dalam peningkatan mutu pendidikan di SD Negeri 3 pancor adalah: 1) Adanya komitmen yang tinggi dari komite sekolah untuk membentu sekolah. 2) Latar belakang pendidikan sebagian anggota komite sekolah dan 3) Kepala sekolah yang selalu proaktif. Dukungan ide, tenaga, dan terjalinnya komunikasi yang baik dari kepala sekolah. Faktor penghambat datang dari komite sekolah itu sendiri seperti kurangnya pemahaman anggota komite sekolah mengenai peran dan fungsi yang harus dijalankan, kurangnya kesadaran masyarakat akan pentingnya kualitas pendidikan, kurangnya dukungan yang diberikan oleh masyarakat terutama dalam hal anggaran dari komite sekolah, serta kesibukan yang dialami oleh komite sekolah itu sendiri

Upaya pemberdayaan komite sekolah untuk memperoleh dukungan dana, tenaga, ide, maupun fasilitas dari komite sekolah di SD Negeri 3 Pancor yaitu dengan cara komite sekolah diundang dalam rapat-rapat sekolah yang bersifat umum dan terbuka, selain itu komite sekolah diundang dalam kegiatan-kegiatan akademik maupun non akademik terkait dengan penggunaan dana dalam rapat pembahasan RAPBS dan rapat pembahasan program kerja tahunan.

Pemberdayaan komite sekolah di SD Negeri 3 Pancor dilakukan dengan cara konsultasi pihak sekolah dengan komite sekolah dalam implementasi program sekolah, misalnya terjadi pada kegiatan penyusunan RAPBS, penyelenggaran 
program Rintisan Sekolah Bertaraf Internasional (RSBI), dan sebagainya. Semuanya dilakukan dengan membicarakan segala masalah, keluhan, dan kemajuan yang terkait dengan pelaksanaan program sekolah. Dengan harapan banyak masukan, ide maupun pendapat terhadap pelaksanaan program sekolah. bentuk pemberdayaan yang nampak adalah masih berbentuk dialog/diskusi saja. Namun bentuk pemberdayaan yang lain seperti komite sekolah berinovasi dan berkreativitas dalam merancang program untuk peningkatan mutu pendidikan masih tdak ada sama sekalai. Mengacu pada pendapat (Ife, 2006, p.67) bahwa:

...empowerment is a process of helping disadvantaged groups and individual to compete more effectively with other interests, by helping them to learn and use in lobbying, using the media, engaging in political action, understanding how to 'work the system,' and so on.

Penjelasan di atas tersebut memberikan gambaran bahwa konsep pemberdayaan (empowerment) sebagai upaya memberikan otonomi, wewenang, dan kepercayaan kepada setiap individu dalam suatu organisasi, serta mendorong mereka untuk kreatif agar dapat menyelesaikan tugasnya sebaik mungkin.

Keputusan/kebijakan yang diambil sekolah dilakukan atas dasar musyawarah mufakat dengan pihak komite sekolah. Keputusan/kebijakan tersebut adalah bersifat umum, strategis, dan keputusan/kebijakan itu memang diatur harus atas persetujuan komite sekolah misalnya penyusunan RAPBS. Namun demikian, ada beberapa keputusan/kebijakan sekolah yang tidak selalu membutuhkan musyawarah mufakat dengan komite sekolah. Keputusan/kebijakan sekolah yang bersifat harian, oprasional, atau juga keputusan/kebijakan yang menyangkut hal-hal yang menjadi otonomi pendidik misalnya penentuan nilai siswa atau kelulusan siswa.

Sinergisitas yang dibangaun menjadi tanggung jawab bersama antar sekolah dan masyarakat sebagai mitra kerja dalam membangun pendidikan. Sinergisitas yang dibangun oleh kedua unsur tersebut akan mencapai hal yang positif untuk kemajuan sekolah. Misalnya masyarakat dapat menyalurkan berbagai ide dan partisipasinya dalam memajukan sekolah untuk mencapai tujuan tersebut maka pemahaman dari unsur-unsur pendidikan tentang hak dan kewajiban yang harus dilaksanakan.

Pemahaman bebrapa anggota komite sekolah mengenai peran dan fungsi komite sekolah di SD Negeri 3 Pancor sudah dapat dikatakan sudah sesuai dengan SK Mendiknas RI No. 044/U/2002 tentang dewan pendidikan dan komite sekolah. 
Komite sekolah di SD Negeri 3 Pancor berperan sebagai pemberi pertimbangan, pendukung, pengontrol, dan penghubung. Dalam dimensi oprasional, komite sekolah di SD Negeri 3 Pancor berperan sebagai pemberi pertimbangan dalam penentuan dan pelaksanaan kebijakan, serta berperan sebagai pendukung sekolah, baik yang berwujud finansial, pemikiran, maupun tenaga dalam peningkatan mutu pendidikan. Namun dukungan yang berwujud finansial masih belum terealisasi dari peran komite sebagai pendukung. Selain itu dalam rangka transparansi dan akuntabilitas penyelenggaraan dan keluaran pendidikan, komite sekolah berperan sebagai pengontrol dan mediator antara pemerintah dan masyarakat. Peran dan tugas komite sekolah inilah yang masih dipandang belum maksimal dilaksanakan di SD Negeri 3 Pancor.

Sosialisasi yang dilakukan mengenai peran dan fungsi komite sekolah di SD Negeri 3 Pancor yang masih belum maksimal dilakukan oleh komite sekolah. Sosialisasi yang dilakukan oleh komite sekolah kepada orang tau siswa dan masyarakat hanyalah sosialiasi semata tanpa ada tindak lanjut dari komite sekolah terutama mengenai progran kerja sekolah. Pembuatan program kerja sekolah disusun atau dirancang dalam rapat, dimana dalam rapat tersebut dihadiri oleh kepala sekolah, komite sekolah, orang tua serta stakeholder lainnya. Selain melaui forum rapat sekolah komite sekolah juga melakukan sosilaisasi melalui surat yang diberikan kepada orang tua siswa

Dalam penanganan sarana prasarana, Komite sekolah belum berperan aktif dalam pengadaan sarana yang bersumber dari swadaya masyarakat. Kerjasama komite sekolah mengenai penambahan fasilitas sekolah berupa banguan fisik sekolah dan keuangan serta masukan inisiatif belum tampak. Bentuk kerjasama antara komite dan sekolah yang diharapkan dapat meningkatkan mutu belajar dalam bentuk dukungan sarana dan prasarana serta memberikan inisitiatif misalnya dalam bentuk pengawasan belajar belum dilakukan oleh komite.

Usaha pemberdayaan Komite Sekolah tersebut dapat dinilai berhasil jika telah tercapai beberapa indikator sebagai berikut (1) proses pembentukan komite sekolah dilakukan melalui proses dan mekanisme yang demokratis, transparan, dan akuntabel; (2) tidak ada lagi Komite Sekolah "stempel' dan Komite Sekolah "eksekutor". Dengan kata lain, komite sekolah yang berhasil dibentuk adalah komite 
sekolah yang memiliki semangat kemitraan dengan sekolah; (3) bila ada permasalahan antara sekolah dan komite sekolah dapat diselesaikan secara mandiri oleh Tim Fasilitator, atau setidaknya dapat diselesaikan pada tingkat Dewan Pendidikan Kabupaten/Kota; (4) secara bertahap diharapkan agar komite sekolah segera dapat melaksanakan peran dan fungsinya secara optimal untuk meningkatkan mutu pendidikan di sekolah (Sulistiyani, 2004, p.94).

\section{SIMPULAN DAN SARAN}

\section{Simpulan}

Pemberdayaan komite masih belum maksimal. Peran komite sekolah dilakukan komite sekolah diantaranya dilakukan melalui pemberian pertimbangan dalam perencanaan program, kebijakan sekolah, pengembangan, pengadaan sarana dan prasarana yang menunjang kenyamanan proes pembelajaran, mengontrol kinerja guru dan hasil belajar peserta didik, dan menjalin kerja sama dan hubungan yanng baik dengan pihak sekolah, wali murid, dan masyarakat dan stakeholder. Namun tidak berjalan maksimal.

Dalam menjalankan perannya, faktor pendukung dan penghambat dalam pelaksanaan peran dan tugas komite sekolah di SDN 3 Pancor yang meliputi: (a) adanya komitmen dukungan ide, tenaga, dan fasilitas yang memadai, komunikasi dan koordinasi yang baik; (d) latar belakang pendidikan anggota komite sekolah; dan (e) kepala sekolah yang selalu proaktif. Sedangkan faktor penghambat pelaksanaan peran dan fungsi komite sekolah diakibatkan oleh (a) Pembiayaan dimana sumber daya masyarakat lokal berupa kemampuan untuk ekonomi di daerah ini rata-rata menengah ke atas namun dengan pemahaman masyarakat dengan adanya dana BOS maka tidak perlu lagi adanya penarikan biaya apapun sehingga berdampak pada sumbangsih masyarakat berupa bantuan keuangan sulit terjangkau, (b) faktor kesibukan pengurus komite sekolah dan waktu pertemuan yang terbatas. Hal ini disebabkan karena sebagian besar dari anggota pengurus komite sekolah menjadi dosen di perguruan tinggi di daerah setempat dan ada juga yang menjadi pengawas. Selama ini uapaya sekolah dalam memberdayakan komite sekolah hanya sebatas diskusi yang sifatnya insidental. 


\section{Saran}

Temuan-temuan yang didapatkan dari hasil penelitian ini masih perlu dikembangkan dan diteliti kembali. Sebaiknya harus dimaksimalkan kembali sinergisitas dan koordinasi antar semua elemen sekolah, baik guru, siswa, komite, pengawas, kepala sekolah hendaknya bahu-membahu dalam merencakan pengembangan sekolah yang lebih baik. Koordinasi dengan komite sekolah sebaiknya tidak hanya secara insidental saja melainkan secara terus menerus dan terencana sehingga mutu sekolah dapat terkendali dengan baik.

\section{DAFTAR PUSTAKA}

Arcaro, J.S. (2007). Pendidikan berasis mutu: prinsip-prinsip perumusan dan tata langkah penerapan. (Terjemahan Yosal Irianta): Yogyakarta. Pustaka Pelajar.

Bafadal I. (2003). Manajmen peningkatan mutu pendidikan sekolah dasar dari sentralisasi menuju desentralisasi. Jakarta: Bumi Aksara.

Deal, T.E. \& Peterson, K.D (2002). The shaping school culture fieldbook. San Francisco: Jossey Bass Company

Hasbulloh. (2006) Otonomi Pendidikan: Kebijakan otonomi daerah dan implikasinya terhadap penyelenggaraan pendidikan. Jakarta: PT Raja Grafindo Persada.

Hoy W.K. \& Ferguson J. (1985). A Theotrical franework and explanation of organizational effectiveness of schools. Administration quarterly. Volume XXI, No.2 spring, halaman 117-132.

Hoy W.K. \& Miskel C.G. (2005). Educational administration: theory, research, and practice, Secon Edition. New York: Random House.

Ife, J. \& Frank T. (2006). Commonity developmen:community-best lternatives in an age globalisasion. Australia: Aquatic drive frenchs forest.

Miles, M.B \& Huberman A.M (2007), Analisis data kualitatif. Jakarta. Universitas Indonesia (UI-Press).

Muhtarom, T., \& Wangid, M. (2013). Studi komparasi budaya sekolah sdsn dan sd eks rsbi di daerah istimewa yogyakarta. Jurnal prima edukasia, 1(2), 195207.

Retrieved from http://journal.uny.ac.id/index.php/jpe/article/view/2636/2191

Republik Indonesia. (2010). Peraturan Pemerintah Republik Indonesia tahun 2010 tentang Pengelolaaan dan Penyelenggaraan Pendidikan.

Sallis. E (2006). Total quality managemen in education. Yogyakarta: IRCiSoD. 
Sastraprateja. (2013). Pendidikan sebagai humanisasi. Jakarta: Pusat Kajian Filsafat dan Pancasila.

Sulistiyani, A.T. (2004). Kemitraan dan model-model pemberdayaan. Yogyakarta: Gava Media.

Suparlan. (2008). Membangun sekolah efektif. Yogyakarta: Hikayat Publishing.

UNICEF. (2000). Defining Quality in Education. New York: The International Working Group on Education Florence.

Uno, Hamzah. (2008). Model pembelajaran, menciptakan proes belajar mengajar kreatif dan epektif. Jakarta: Bumi Aksara.

Wangid, M., Mustadi, A., Erviana, V., \& Arifin, S. (2014). Kesiapan guru sd dalam pelaksanaan pembelajaran tematik-integratif pada kurikulum 2013 di diy. Jurnal Prima Edukasia, 2(2), 175-182. Retrieved fromhttp://journal.uny.ac.id/index.php/jpe/article/view/2717

Zamroni. (2013). Pendidikan demokrasi pada masyarakat multikultural. Yogyakarta: Ombak.

Zamroni_ (2001). Pendidikan untuk demokrasi (tantangan menuju civisi society). Yogyakarta: Bigraf Publising. 